\title{
Classic phenylketonuria
}

INSERM

\section{Source}

INSERM. (1999). Orphanet: an online rare disease and orphan drug data base. Classic phenylketonuria. ORPHA:79254

Classical phenylketonuria is a severe form of phenylketonuria (PKU, see this term) an inborn error of amino acid metabolism characterized in untreated patients by severe intellectual deficit and neuropsychiatric complications. 